\title{
Isolation, Identification and Optimization of Phenanthrene Degrading Bacteria From the Coastal Sediments of Nayband Bay
}

\author{
Mohsen Shahriari Moghadam ${ }^{1, *}$, Gholamhossein Ebrahimipour ${ }^{2}$, Behrooz Abtahi ${ }^{1}$, Alireza \\ Ghassempour $^{3}$ \\ ${ }_{1}^{1}$ Department of Marine Biology, Faculty of Biological Science, Shahid Beheshti University, G.C., Tehran, IR Iran \\ ${ }_{3}^{2}$ Department of Microbiology, Faculty of Biological Science, Shahid Beheshti University, , G.C., Tehran, IR Iran \\ ${ }^{3}$ Department of Phytochemistry, Medicinal Plants and Drugs Research Institute, Shahid Beheshti University,G.C., Tehran, IR Iran \\ ${ }^{*}$ Corresponding author: Mohsen Shahriari Moghadam, Department of Marine Biology, Faculty of Biological Science, Shahid Beheshti University, P.O. Box: 19835-389, Tehran, IR Iran. \\ Tel: +98-9159429131, Fax:+98-2122431664, E-mail: mohsen.mshahriari@gmail.com.
}

Received: July 27, 2013; Revised: September 8, 2013; Accepted: September 23, 2013

\begin{abstract}
Background:Biodegradation of polycyclic aromatic hydrocarbons(PAHs) contaminated sediments is an effective remediation technique and its success depends on the optimal condition of PAH-degrading isolates.

Objectives: The present study was conducted to isolate the PAHs-degrading bacteria from Nayband bay mangrove sediments and to investigate the effect of different variables on phenanthrene (Phe) biodegrading efficiency of the most effective isolated strains, by using response surface methodology (RSM).

Materials and Methods: Phe degrading bacteria were isolated from surface sediments. Isolated strains were then identified by biochemical and molecular (16S rDNA gene sequence) analysis. RSM was employed to evaluate the optimum biodegradation of Phe by the most effective isolated strain. The investigated parameters included the temperature, inoculum sizes, $\mathrm{pH}^{\mathrm{NH}} \mathrm{Cl}_{4}$ concentration, and salinity.

Results: One Gram-negative bacterium strain(SBU1) was isolated from enrichment consortium SBU.SBU1 have been identified by 16S rDNA sequence analysis and revealed $96 \%$ homology with Roseovarius sp., the biodegradation activity of the SBU1 was properly interpreted using a second-order polynomial regression model. Maximum biodegradation efficiency was predicted at $\mathrm{pH}=8.2$, temperature $\approx 35^{\circ} \mathrm{C}$, salinity $=30 \mathrm{ppt}, \mathrm{NH}_{4} \mathrm{Cl}$ concentration $=0.13 \mathrm{~g} / \mathrm{L}$ and inoculum size $=0.2 \mathrm{OD}_{600 \mathrm{~nm}}$. Under these conditions the aerobic biodegradation rate reached up to $28.4 \%$.

Conclusions:Indigenous bacteria from mangrove surface sediments of Nayband bay were found to be able to degrade Phe. The similarity of the predicted and observed results confirmed the validity and applicability of RSM in optimization processes.
\end{abstract}

Keywords: RSM; PAHs; Biodegradation

\section{Background}

Mangroves are known as important inter-tidal estuarine wetlands along the tropical and subtropical coastlines. These ecosystems are closely tied to human activities and are very vulnerable to anthropogenic contaminations mainly due to their inherent physical and chemical properties such as rich organic contents and the anaerobic and reduced phase condition of the soil $(1,2)$.

Natural polycyclic aromatic hydrocarbons (PAHs) as well as those produced by human activities are widely detected in coastal environments and accumulate in mangrove sediments (3). The US environmental protection agency (EPA) has listed 16 PAHs as particularly hazardous agents due to their carcinogenic and mutagenic properties (4). Among these agents, phenanthrene (Phe) - a three ring constituent of coal derivatives and oil fuels- is considered as one of the prior pollutants. It is reported to act as human skin photosensitiser, a mild allergen and also a mutagen in bacterial systems (5).

With the discovery of a wide variety of microorganisms that are capable to degrade PAHs (6), bioremediation- a technology that utilizes the microorganisms to eliminate the environmental contaminants- has become a popular and effective remediation technique (7). To date, large varieties of bacteria which are able to use PAHs as the sole carbon and energy source have been isolated from the mangrove sediments (8-10) but success of bioremediation has been found to largely depended on different biotic and abiotic factors such as bacterial population size, temperature, $\mathrm{pH}$, nutrient, salinity, etc. (11-13). Moreover, the effect of a single factor seems not straightforward in fashion since it is often is influenced by the presence 
and levels of other factors. For instance, temperature has been reported to affect the PAH bioavailability and both temperature and PAH bioavailability have been shown to affect the activity of microorganisms (7).

In essence, the application of appropriate statistical methods seems mandatory for the accurate study of these interactions. Response surface methodology (RSM) is a collection of mathematical and statistical techniques that are useful for modeling and analysis of problems in which the response of interest is influenced by several variables. This method has been successfully applied to optimize the biodegradation of toxic substances (14).

\section{Objectives}

The Nayband bay, a protected coastal region located in the northern Persian gulf, is a suitable place for restoration of ecologically important habitats such as coral reefs, seagrass beds, and mangrove forests. However, in recent years, growing industrial activities in that area is threating different habitats located in the Bay. The aims of the present study were to isolate the PAHs-degrading bacteria from mangrove sediments and to investigate the effect of five different abiotic and biotic factors including bacterial population size, temperature, $\mathrm{pH}, \mathrm{NH}_{4} \mathrm{Cl}$ concentration and salinity on Phe biodegradation, using RSM.

\section{Materials and Methods}

\subsection{Sediment Sampling and Enrichment of Phe-De- grading Bacterial Consortium}

Aerobic surface sediment samples were randomly collected from the mangrove forests at Nayband bay- Iran during low tides. To enrich Phe-degrading bacterial consortium, a predetermined amount of phenanthrene (Merck, Germany) was dissolved in acetone in a $250 \mathrm{~mL}$ conical flask to obtain the final concentration of 1000 $\mathrm{mg} / \mathrm{L}$. The solution was kept at room temperature until complete evaporation of the solvent (acetone) and then the flask was filled with $45 \mathrm{~mL}$ sterilized mineral salt me$\operatorname{dium}(\mathrm{MSM})\left(1.0 \mathrm{~g} \mathrm{NH}_{4} \mathrm{Cl}, 0.5 \mathrm{~g} \mathrm{~K}_{2} \mathrm{HPO}_{4}, 0.01 \mathrm{~g} \mathrm{FeSO}_{4} .7 \mathrm{H}_{2} \mathrm{O}\right.$ in $1 \mathrm{~L} 0.45 \mu \mathrm{m}$ Millipore-filtered 40ppt local seawater). Then, approximately $5 \mathrm{~g}$ of the fresh sediment sample was transferred into the conical flask and the solution $\mathrm{pH}$ was adjusted to 8.0. The flask was incubated at $30^{\circ} \mathrm{C}$ on a rotary shaker at $140 \mathrm{rpm}$ during of which PAH utilization in the enriched cultures was monitored by signs of decreased amounts of Phe crystals, that is presented with medium color changes (from pale color to dark red), and increased bacterial biomass. At the end, $5 \mathrm{~mL}$ of the enriched culture was transferred to the fresh medium and incubated under the same condition. This process was repeated for four times to obtain the enriched Phedegrading consortium.

\subsection{Isolation and Identification of Bacterial Strains}

At the end of the enrichment, bacterial strains in the consortium were isolated by spreading the 10 -fold serially diluted consortium on Mineral salt medium agar plates coated with a layer of Phe. Bacterial colonies were then collected from the plates, and purified by repetitive streaking onto nutrient agar plates (Quelab Laboratories Inc. Montreal, Canada). Purified strains were identified by biochemical tests such as Gram staining and oxidation/fermentation tests (15). Further molecular identification of the strains was also performed by $16 \mathrm{~S}$ rDNA gene sequences analysis. For this purpose, DNAs of the isolated bacteria were extracted using the bacterial DNA extraction kit (Roche ${ }^{\circledR}$ - Germany).

The isolated strains were then identified by $16 \mathrm{~S}$ rDNA gene sequence analysis after amplification of the gene by PCR using the set of primers 27F (5- AGA GTT TGA TCC TGG CTC AG-3) and 1510R (5-GGT TAC CTT ACG ACT T-3). The reactions were cycled in a Primus 25 advanced ${ }^{\circledR}$ thermocycler with an initial denaturation step at $95^{\circ} \mathrm{C}$ for 5 minutes followed by 35 cycles of denaturation at $94^{\circ} \mathrm{C}$ for 1 minute, annealing at $52^{\circ} \mathrm{C}$ for $1: 30$ minute and extension at $72^{\circ} \mathrm{C}$ for 1 minute, and a final extension step at $72^{\circ} \mathrm{C}$ for 15 minute. DNA sequences of the cloned 16S rDNA fragments compared using BLAST at http://www.ncbi.nlm. nih.gov/BLAST/ (National Center of Biotechnology Information, NCBI).

\subsection{Assessment of Biodegradation}

The most effective isolated strain was first cultivated on nutrient broth at $30^{\circ} \mathrm{C}$ for 3 days, after that the cells were collected by centrifugation at 8000 rpm for $15 \mathrm{~min}$ utes, and washed twice with sterilized sea water. In order to assess the basal Phe utilization rates, the microbial inoculums with final optical density $\left(\mathrm{OD}_{600 \mathrm{~nm}}\right)$ of 0.15 were passed to the MSM $\left(1.0 \mathrm{~g} \mathrm{NH}_{4} \mathrm{Cl}, 0.5 \mathrm{~g} \mathrm{~K}_{2} \mathrm{HPO}_{4}, 0.01 \mathrm{~g}\right.$ $\mathrm{FeSO}_{4} .7 \mathrm{H} 2 \mathrm{O}$ in $1 \mathrm{~L} 0.45 \mu \mathrm{m}$ Millipore-filtered $40 \mathrm{ppt}$ local seawater)+ Phe medium. The experimental cultures were performed in triplicate at $30^{\circ} \mathrm{C}$ in the dark at $140 \mathrm{rpm}$ for 10 days. To determine the abiotic losses of Phe, the same MSM media without any microbial inoculum were also retained. The entire medium was used for further analysis of Phe concentrations at the end of each experiment.

\subsection{Experimental Design and Statistical Analysis}

The optimization of Phe biodegradation efficiency was examined by using the RSM with a 5-level, 5 -factor central composite design (CCD). The selected variables were temperature, inoculum sizes, $\mathrm{pH}, \mathrm{NH}_{4} \mathrm{Cl}$ concentration, and salinity. Coded and actual values of the five variables, as well as composites of their combination sets are presented in Table 1. In order to reach to the initial in oculum sizes determined by RSM experimental design, the strain was first cultured on nutrient broth for 3 days at $30^{\circ} \mathrm{C}$. The cells were then collected by centrifugation at 
Shahriari Moghadam M et al.

$8000 \mathrm{rpm}$ for 15 minutes, and washed twice with sterilized sea water. For each experiment, Phe were used as a sole carbon source and spiked into the $250 \mathrm{~mL}$ conical flask at $1000 \mathrm{mg} / \mathrm{L}$ concentration. Each experimental experiment was conducted in triplicate at $140 \mathrm{rpm}$ shak- ing schedule. Parallel controls were also setup to assess a biotic losses. These trials contained the same aqueous volume and contaminant concentration but were not inoculated.

\begin{tabular}{|c|c|c|c|c|c|c|}
\hline Treatment & $\begin{array}{l}\text { Optical Density, } \\
\text { OD600 }\left(x_{1}\right)\end{array}$ & $\mathbf{p H}\left(\mathbf{x}_{2}\right)$ & Temperature, ${ }^{\circ} \mathrm{C}\left(\mathrm{x}_{\mathbf{3}}\right)$ & $\mathrm{NH}_{4} \mathrm{Cl}, \mathrm{g} / \mathrm{L}\left(\mathrm{x}_{4}\right)$ & Salinity, ppt $\left(\mathbf{x}_{\mathbf{5}}\right)$ & $\begin{array}{l}\text { Biodegradation Effi- } \\
\text { ciency, } \%(Y)\end{array}$ \\
\hline $\mathbf{1}$ & $0.2(+1)$ & $6.5(-1)$ & $35(+1)$ & $0.08(-1)$ & $40(+1)$ & $15.20 \pm 1.71$ \\
\hline 2 & $0.2(+1)$ & $6.5(-1)$ & $35(+1)$ & $0.16(+1)$ & $30(-1)$ & $7.00 \pm 1.00$ \\
\hline 3 & $0.2(+1)$ & $8.5(+1)$ & $35(+1)$ & $0.08(-1)$ & $30(-1)$ & $26.33 \pm 2.08$ \\
\hline 4 & $0.1(-1)$ & $8.5(+1)$ & $25(-1)$ & $0.16(+1)$ & $40(+1)$ & $23.42 \pm 2.00$ \\
\hline 5 & $0.05(-2)$ & $7.5(0)$ & $30(0)$ & $0.12(0)$ & $35(0)$ & $13.79 \pm 2.55$ \\
\hline 6 & $0.15(0)$ & $7.5(0)$ & $20(-2)$ & $0.12(0)$ & $35(0)$ & $11.67 \pm 1.53$ \\
\hline 7 & $0.2(+1)$ & $8.5(+1)$ & $25(-1)$ & $0.16(+1)$ & $30(-1)$ & $21.72 \pm 3.81$ \\
\hline 8 & $0.1(-1)$ & $6.5(-1)$ & $35(+1)$ & $0.08(-1)$ & $30(-1)$ & $16.64 \pm 1.88$ \\
\hline 9 & $0.15(0)$ & $9.5(+2)$ & $30(0)$ & $0.12(0)$ & $35(0)$ & $7.26 \pm 1.39$ \\
\hline 10 & $0.15(0)$ & $7.5(0)$ & $30(0)$ & $0.12(0)$ & $35(0)$ & $21.33 \pm 4.51$ \\
\hline 11 & $0.15(0)$ & $7.5(0)$ & $30(0)$ & $0.12(0)$ & $45(+2)$ & $8.45 \pm 1.39$ \\
\hline 12 & $0.15(0)$ & $7.5(0)$ & $30(0)$ & $0.12(0)$ & $25(-2)$ & $20.67 \pm 3.06$ \\
\hline 13 & $0.2(+1)$ & $8.5(+1)$ & $25(-1)$ & $0.08(-1)$ & $40(+1)$ & $17.03 \pm 2.90$ \\
\hline 14 & $0.1(-1)$ & $6.5(-1)$ & $25(-1)$ & $0.08(-1)$ & $40(+1)$ & $2.94 \pm 1.01$ \\
\hline 15 & $0.15(0)$ & $7.5(0)$ & $30(0)$ & $0.12(0)$ & $35(0)$ & $14.49 \pm 2.27$ \\
\hline 16 & $0.15(0)$ & $7.5(0)$ & $30(0)$ & $0.12(0)$ & $35(0)$ & $14.39 \pm 1.82$ \\
\hline 17 & $0.1(-1)$ & $6.5(-1)$ & $35(+1)$ & $0.16(+1)$ & $40(+1)$ & $7.13 \pm 1.40$ \\
\hline 18 & $0.25(+2)$ & $7.5(0)$ & $30(0)$ & $0.12(0)$ & $35(0)$ & $21.03 \pm 2.03$ \\
\hline 19 & $0.15(0)$ & $7.5(0)$ & $30(0)$ & $0.04(-2)$ & $35(0)$ & $19.55 \pm 2.86$ \\
\hline 20 & $0.15(0)$ & $5.5(-2)$ & $30(0)$ & $0.12(0)$ & $35(0)$ & $1.74 \pm 1.27$ \\
\hline 21 & $0.15(0)$ & $7.5(0)$ & $40(+2)$ & $0.12(0)$ & $35(0)$ & $23.71 \pm 2.06$ \\
\hline 22 & $0.1(-1)$ & $6.5(-1)$ & $25(-1)$ & $0.16(+1)$ & $30(-1)$ & $6.10 \pm 0.10$ \\
\hline 23 & $0.1(-1)$ & $8.5(+1)$ & $35(+1)$ & $0.08(-1)$ & $40(+1)$ & $26.08 \pm 1.67$ \\
\hline 24 & $0.15(0)$ & $7.5(0)$ & $30(0)$ & $0.12(0)$ & $35(0)$ & $21.85 \pm 0.33$ \\
\hline 25 & $0.1(-1)$ & $8.5(+1)$ & $35(+1)$ & $0.16(+1)$ & $30(-1)$ & $27.32 \pm 0.68$ \\
\hline 26 & $0.2(+1)$ & $6.5(-1)$ & $25(-1)$ & $0.08(-1)$ & $30(-1)$ & $6.02 \pm 0.98$ \\
\hline 27 & $0.2(+1)$ & $8.5(+1)$ & $35(+1)$ & $0.16(+1)$ & $40(+1)$ & $22.61 \pm 1.39$ \\
\hline 28 & $0.15(0)$ & $7.5(0)$ & $30(0)$ & $0.12(0)$ & $35(0)$ & $20.61 \pm 2.15$ \\
\hline 29 & $0.15(0)$ & $7.5(0)$ & $30(0)$ & $0.12(0)$ & $35(0)$ & $15.33 \pm 2.08$ \\
\hline 30 & $0.2(+1)$ & $6.5(-1)$ & $25(-1)$ & $0.16(+1)$ & $40(+1)$ & $5.50 \pm 1.50$ \\
\hline 31 & $0.1(-1)$ & $8.5(+1)$ & $25(-1)$ & $0.08(-1)$ & $30(-1)$ & $20.42 \pm 2.98$ \\
\hline 32 & $0.15(0)$ & $7.5(0)$ & $30(0)$ & $0.2(+2)$ & $35(0)$ & $19.35 \pm 2.09$ \\
\hline
\end{tabular}

The entire medium of each flask was used for analysis of Phe concentrations after 10 days from experiment. Concentration of Phe was determined by GC-FID equipped with a HP-5MS fused silica capillary column according to Wu et al.(16). The Phe biodegradation rates (\%) were fitted to a second-order polynomial model (equation 1) and the regression coefficients were obtained. 
Equation 1.

$$
Y=\beta_{k 0}+\sum_{i=1}^{5} \beta_{k i} x_{i}+\sum_{i=1}^{5} \beta_{k i i} x_{i}^{2}+\sum_{i=1}^{4} \sum_{j=i+1}^{5} \beta_{k i j} x_{i} x_{j}
$$

where $\mathrm{Y}$ is response (\%Phe biodegradation); $\beta_{\mathrm{k} 0}, \beta_{\mathrm{ki}}, \beta_{\mathrm{kii}}$ and $\beta_{\mathrm{kij}}$ are constant coefficients and $\mathrm{x}_{\mathrm{i}}$ is the uncoded independent variables; $\mathrm{x}_{1}=$ Optical Density $\left(\mathrm{OD}_{600 n m}\right) ; \mathrm{x}_{2}=\mathrm{pH} ; \mathrm{x}_{3}=$ Temperature $\left({ }^{\circ} \mathrm{C}\right) ; \mathrm{x}_{4}=\mathrm{NH}_{4} \mathrm{Cl}(\mathrm{g} / \mathrm{L}) ; \mathrm{x}_{5}=$ Salinity $(\mathrm{ppt})$.

The observed responses (\% of Phe biodegradation) were subjected to the analysis of variance (ANOVA) and regression to seek for an optimized level of factors (Design Expert V 7.0.10, Stat-Ease Inc., Minneapolis, 2005). The efficiency of the achieved optimized cultural condition was then tested during a 10-day experiment.

\section{Results}

\subsection{Identification of Microbial Strains}

A Gram-negative bacterium strain (SBU1) was isolated from enrichment consortium SBU cultured on MSM agar plates coated with a layer of Phe. The isolated strain was cocco-shaped, forming small raised creamy colonies on nutrient agar medium. Differential biochemical and phenotypic characteristics of strain SBU1 are shown in Table 2. The $16 \mathrm{~S}$ rDNA sequence obtained in this study (GenBank database accession number:KF052989) showed 96\% similarity with Roseovarius sp. The SBU1 degraded $<15 \%$ of Phe after 10 days.

4.2. Optimization of the Quadratic Model of Phenanthrene Biodegradation

The degradation rate of Phe ranged from 2.94\% (run order 14 ) to $27.32 \%$ (run order 25 ).

Table 2. Differential Biochemical and Phenotypic Characteristics of Strain SBU1

\begin{tabular}{ll}
\hline Characteristic & Strain SBU1 \\
\hline Motility & + \\
\hline Anaerobic growth & - \\
\hline Growth in NaCl, \% & $1-20$ \\
\hline Growth temperature, ${ }^{\circ} \mathrm{C}$ & \\
\hline $\mathbf{4}$ & - \\
\hline 37 & + \\
\hline Oxidase & + \\
\hline Catalase & + \\
\hline Gelatinase & - \\
\hline Amylase & - \\
\hline Reduction of Nitrate to $\mathrm{Nitrite}^{2}$ & + \\
\hline Reduction of Nitrite to $\mathbf{N}_{\mathbf{2}}$ & + \\
\hline Bchl & \\
\hline
\end{tabular}

${ }^{\mathrm{a}}$ Bacteriochlorophyll

The resulted second-order quadratic polynomial equa-

tion achieved by optimization of process variables was shown as below:

$$
\begin{aligned}
\operatorname{Ln}(Y)=+2.84 & +0.038 x_{1}+0.50 x_{2}+0.22 x_{3}-0.030 x_{4}-0.12 x_{5}-0.059 x_{1} x_{2} \\
& -0.040 x_{1} x_{3}-0.053 x_{1} x_{4}+0.11 x_{1} x_{5}-0.14 x_{2} x_{3}+0.079 x_{2} x_{4} \\
& +0.037 x_{2} x_{5}-0.17 x_{3} x_{4}+0.041 x_{3} x_{5}+0.050 x_{4} x_{5}+0.019 x_{1}^{2}-0.37 x_{2}^{2} \\
& +0.013 x_{3}^{2}+0.052 x_{4}^{2}-0.044 x_{5}^{2}
\end{aligned}
$$


Shahriari Moghadam M et al.

Analysis of variance indicated that the second order polynomial model was significant $(\mathrm{P}<0.05)$ and effective $\left(r^{2}=0.94\right)$ in representing the actual effects of the variable on Phe biodegradation (Table 3 ).

Table 3. Analysis of Variance (ANOVA) for Quadratic and Regression Statistics

\begin{tabular}{|c|c|c|c|c|c|c|c|c|c|c|}
\hline & \multicolumn{5}{|c|}{ Full Model $^{\mathrm{a}}$} & \multicolumn{5}{|c|}{ Reduced Model $^{\mathrm{b}}$} \\
\hline & $\begin{array}{l}\text { Sum of } \\
\text { Squares }\end{array}$ & $\begin{array}{l}\text { Degrees of } \\
\text { Freedom }\end{array}$ & $\begin{array}{l}\text { Mean } \\
\text { Square }\end{array}$ & F Value & Pvalue & $\begin{array}{l}\text { Sum of } \\
\text { Squares }\end{array}$ & $\begin{array}{l}\text { Degrees of } \\
\text { Freedom }\end{array}$ & Mean Square & F Value & P value \\
\hline Model & 13.36 & 20 & 0.67 & 9.48 & 0.000 & 12.36 & 6 & 2.06 & 28.90 & 0.000 \\
\hline $\begin{array}{l}\text { Inoculum size, } \\
\text { OD }_{600 n m},\left(x_{1}\right)\end{array}$ & 0.035 & 1 & 0.035 & 0.49 & 0.497 & - & - & - & - & - \\
\hline $\mathbf{p H}\left(\mathbf{x}_{2}\right)$ & 6.07 & 1 & 6.07 & 86.12 & 0.000 & 6.07 & 1 & 6.07 & 85.18 & 0.000 \\
\hline $\begin{array}{l}\text { Temperature, } \\
{ }^{\circ} \mathbf{C},\left(\mathbf{x}_{3}\right)\end{array}$ & 1.19 & 1 & 1.19 & 16.92 & 0.001 & 1.19 & 1 & 1.19 & 16.73 & 0.000 \\
\hline $\mathrm{NH}_{4} \mathrm{Cl}, \%,\left(\mathbf{x}_{4}\right)$ & 0.022 & 1 & 0.022 & 0.31 & 0.586 & 0.022 & 1 & 0.022 & 0.31 & 0.581 \\
\hline $\begin{array}{l}\text { Salinity, ppt, } \\
\left(\mathbf{x}_{5}\right)\end{array}$ & 0.37 & 1 & 0.37 & 5.27 & 0.042 & 0.37 & 1 & 0.37 & 5.22 & 0.0311 \\
\hline $\mathbf{x}_{1} \mathbf{x}_{2}$ & 0.055 & 1 & 0.055 & 0.79 & 0.394 & - & - & - & - & - \\
\hline $\mathbf{x}_{1} \mathbf{x}_{3}$ & 0.026 & 1 & 0.026 & 0.37 & 0.556 & - & - & - & - & - \\
\hline $\mathbf{x}_{1} \mathbf{x}_{4}$ & 0.044 & 1 & 0.044 & 0.63 & 0.445 & - & - & - & - & - \\
\hline $\mathbf{x}_{1} \mathbf{x}_{5}$ & 0.20 & 1 & 0.20 & 2.80 & 0.122 & - & - & - & - & - \\
\hline $\mathbf{x}_{2} \mathbf{x}_{3}$ & 0.30 & 1 & 0.30 & 4.22 & 0.064 & - & - & - & - & - \\
\hline $\mathbf{x}_{2} \mathbf{x}_{4}$ & 0.099 & 1 & 0.099 & 1.40 & 0.261 & - & - & - & - & - \\
\hline $\mathbf{x}_{2} \mathbf{x}_{5}$ & 0.022 & 1 & 0.022 & 0.31 & 0.591 & - & - & - & - & - \\
\hline $\mathbf{x}_{3} \mathbf{x}_{4}$ & 0.47 & 1 & 0.47 & 6.70 & 0.025 & 0.47 & 1 & 0.47 & 6.63 & 0.016 \\
\hline $\mathbf{x}_{3} \mathbf{x}_{5}$ & 0.27 & 1 & 0.27 & 0.38 & 0.549 & - & - & - & - & - \\
\hline $\mathbf{x}_{4} \mathbf{x}_{5}$ & 0.040 & 1 & 0.040 & 0.57 & 0.467 & - & - & - & - & - \\
\hline $\mathbf{x}_{1}^{2}$ & 0.011 & 1 & 0.011 & 0.15 & 0.706 & - & - & - & - & - \\
\hline $\mathbf{x}_{2}^{2}$ & 4.08 & 1 & 4.08 & 57.85 & 0.000 & 4.23 & 1 & 4.23 & 59.35 & 0.000 \\
\hline $\mathbf{x}_{3}^{2}$ & 4.99 & 1 & 4.99 & 0.071 & 0.795 & - & - & - & - & - \\
\hline $\mathbf{x}_{4}^{2}$ & 0.08 & 1 & 0.08 & 1.13 & 0.310 & - & - & - & - & - \\
\hline $\mathbf{X}_{5}^{2}$ & 0.058 & 1 & 0.058 & 0.82 & 0.383 & - & - & - & - & - \\
\hline Residual error & 0.78 & 11 & 0.70 & - & - & 1.78 & 25 & 0.071 & - & - \\
\hline Lack-of-fit & 0.57 & 6 & 0.095 & 2.30 & 0.188 & 1.58 & 20 & 0.079 & 1.91 & 0.243 \\
\hline Pure error & 0.21 & 5 & 0.041 & - & - & 0.21 & 5 & 0.041 & - & - \\
\hline Total & 14.14 & 31 & - & - & - & 14.14 & 31 & - & - & - \\
\hline
\end{tabular}

a Full model: Coefficient of determination $\left(\mathrm{r}^{2}\right)=0.945$; Adjusted $\mathrm{r}^{2} 0.84$

$\mathrm{b}$ Reduced model: Coefficient of determination $\left(\mathrm{r}^{2}\right)=0.87$; Adjusted $\mathrm{r}^{2} 0.84$

Normally, a regression model that possess an $r^{2}$ value higher than 0.9 is considered a very high correlation (17). The results revealed the statistically significant ( $P$ $<0.05)$ effects of $\mathrm{pH}\left(\mathrm{X}_{2}\right)$, temperature $\left(\mathrm{X}_{3}\right)$ salinity $\left(\mathrm{X}_{5}\right)$, $\mathrm{pH} 2\left(\mathrm{X}_{2}{ }_{2}\right)$, or temperature $\mathrm{x} \mathrm{NH_{4 }} \mathrm{Cl}$ concentration $\left(\mathrm{X}_{3}\right.$ $\mathrm{X}_{4}$ ) on Phe biodegradation, whereas, Optical Density $\left(\mathrm{X}_{3}\right)$ and $\mathrm{NH}_{4} \mathrm{Cl}\left(\mathrm{X}_{4}\right)$ did not show significant effects.

When interactive surface contour was plotted for $\mathrm{NH}_{4} \mathrm{Cl}$ concentration and temperature, the removal of
Phe was found to increase with the decrease of $\mathrm{NH}_{4} \mathrm{Cl}$ concentration and the increase in temperature. As a result, a lower $\mathrm{NH}_{4} \mathrm{Cl}$ concentration and a higher $\mathrm{pH}$ seemed to be mandatory for maximum biodegradation percentage (Figure 1). In order to improve the model prediction, only significant elements were included in the model. The reduced model which describes the response as a function of significant variables is shown below (Equation 3).

$$
\operatorname{Ln}(Y)=+2.88+0.50 x_{2}+0.22 x_{3}-0.03 x_{4}-0.12 x_{5}-0.17 x_{3} x_{4}-0.38 x_{2}^{2}
$$

Equation 3. 
Small $\mathrm{r}^{2}$ values resulted when reduced model was used, but when the similar adjusted values were obtained in both models, then the reduced model was constituted the preferred model. The validity of the model was tested by conducting experiments considering the best predicted conditions (Table 4). Maximum biodegradation efficiency of $28.4 \%$ was obtained at $\mathrm{pH}=8.2$, temperature $\approx 35^{\circ} \mathrm{C}$, salinity $=30 \mathrm{ppt}, \mathrm{NH}_{4} \mathrm{Cl}=0.13 \mathrm{~g} / \mathrm{L}$ and inoculum size $=0.2 \mathrm{OD} 600 \mathrm{~nm}$. In all experiments, the practically achieved biodegradation rates were consistent with predicted values. The abiotic elimination of Phe during biodegradation experiments was negligible.

\begin{tabular}{|c|c|c|c|c|c|c|}
\hline pH & Tempreature, ${ }^{\circ} \mathrm{C}$ & Salinity, ppt & $\mathrm{NH}_{4} \mathrm{Cl}, \mathrm{g} / \mathrm{L}$ & Inoculum $\left(\mathrm{OD}_{600 \mathrm{~nm}}\right)$ & $\begin{array}{l}\text { Biodegradation of } \\
\text { Predicted Values , } \%\end{array}$ & $\begin{array}{l}\text { Biodegradation of Ex- } \\
\text { perimental Values, \% }\end{array}$ \\
\hline 8.20 & 34.8 & 30 & 0.13 & 0.2 & 27.34 & 28.4 \\
\hline 8 & 34.7 & 32.34 & 0.12 & 0.2 & 27.37 & 27.9 \\
\hline 8.20 & 33.5 & 30.8 & 0.12 & 0.14 & 27.34 & 26.10 \\
\hline
\end{tabular}

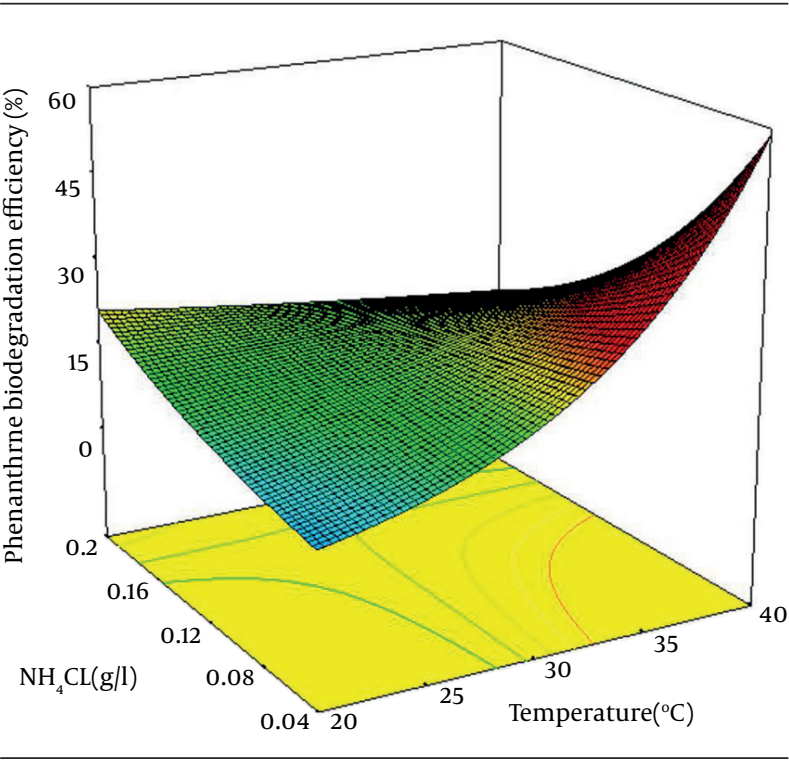

Figure 1. A Three-Dimensional Interactive Surface Contour Which Displays the Effects of $\mathrm{NH}_{4} \mathrm{Cl}$ Concentration and Temperature Level on the Phe Biodegradation

\section{Discussion}

Bioremediation provides a cheap and environmentally safe way to remove toxic pollutants from the environment (18). In the current study, the bacterial strain, SBU1, isolated from mangrove surface sediments, was found accountable in Phe biodegradation.

In general, the SBU1 showed a low Phe biodegrading activity in pure cultures reaching to $28.4 \%$ even after optimization process. Although the PAHs degrading activities of the bacterial consortium belong to the genus Roseovarius have been reported in literature $(19,20)$ and any research on PAHs degrading activities of the Roseovarius sp. in pure culture condition has been done up to date and also several studies have suggested that biodegradation performed by mixed culture would be more effective than those pure cultures which may be due to a broader enzymatic capability and counteraction of toxic intermediates by co-metabolic processes (21).

In our study, the optimum culture conditions for Phe degradation by SBU1 were successfully determined by RSM. Previous studies have shown that the application of statistical experimental design techniques can result in improved yields of degradation and allow rapid and economical determination of the optimum culture conditions with fewer number of experiments and minimal resources in biodegradation processes $(22,23)$.

The optimum degradation conditions were determined as: $\mathrm{pH}=8.2$, temperature $\approx 35^{\circ} \mathrm{C}$, salinity $=30 \mathrm{ppt}, \mathrm{NH}_{4} \mathrm{Cl}$ $=0.13 \mathrm{~g} / \mathrm{L}$ and inoculum size $=0.2 \mathrm{OD}_{600 \mathrm{~nm}}$. Under these conditions, degradation rate of approximately $28.4 \%$ were achieved within 10 days, which was approximately 2 times more than the basal condition.

Among examined factors, Inoculum size and $\mathrm{NH}_{4} \mathrm{Cl}$ concentration had no significant effects, which indicating that biodegradation with small inoculums size and low $\mathrm{NH}_{4} \mathrm{Cl}$ concentration may also be applicable.

The $\mathrm{pH}$ has been found as the most important factor affecting biodegradation in the current study (effect size $=85.18$ ). The $\mathrm{pH}$ of culture medium can affect microbial diversity and activity through altering the enzymatic activity, transporting processes and the nutrient solubility ( 24 ). Leahy and Colwell et al. ( 25 ) have reported that most petroleum degrading bacterial species have degrading property at $\mathrm{pH}=6-8$, but the optimum degradation abilities is observed at $\mathrm{pH}$ near 7 . The biodegradation process was active at a $\mathrm{pH}$ range from 5.5 to 9.5 in the current study, but the highest biodegradation rate (23\%) was obtained at $\mathrm{pH} \approx 8$ (Figure 2 ). 


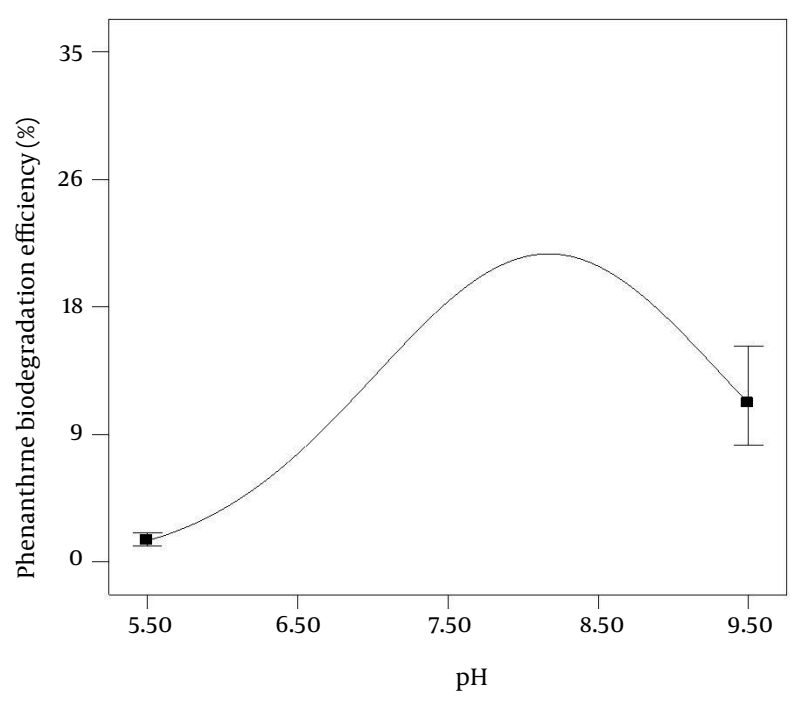

Figure 2. Phenantrene Biodegradation Efficiency at Different pH Levels

Temperature was found as the next effective factor affecting the biodegradation process (effect size $=16.73$ ). In general this factor is one of the most important factors affecting biodegradation of petroleum hydrocarbons through its positive effects on bacterial metabolism (25, 26). In our experiment, the best SBU1 biodegrading efficiency was achieved at nearly highest temperatures $\left(35^{\circ} \mathrm{C}\right)$. This could be due to the increased solubility of PAHs at higher temperatures, which is causing a noticeable improvement in the bioavailability of Phe molecules (27).

Also Salinity was found to have an important role on biodegradation (effect size $=5.22$ ) Shiaris et al.(18) found positive correlation between salinity and Phe biodegradation rates and naphthalene in estuarine sediment but in the contrast, some researchers, reported decreased rates of hydrocarbon metabolisms when salinity was increased and concluded that this may be due to negative effects of ions on metabolism of bacterial cells (24). Our results supposed that 30-33 ppt salinity levels would optimize the Phe biodegradation performed by SBU1.

Analyses results also revealed significant interactions between $\mathrm{NH}_{4} \mathrm{Cl}$ concentration and temperature $(\mathrm{P}=0.016)$. When interactive surface contours were generated for $\mathrm{NH}_{4} \mathrm{Cl}$ concentration and temperature, the removal of Phe was found to increase with decreased amount of $\mathrm{NH}_{4} \mathrm{Cl}$ concentration and increased amount of temperature. Thus, a lower $\mathrm{NH}_{4} \mathrm{Cl}$ concentration and a higher temperature seemed to be needed for the maximum biodegradation percentage.

In conclusion, our findings showed that, indigenous bacteria from mangrove surface sediments of Naybandbay are capable to degrade Phe. The similarity of the predicted and the observed results confirmed the validity and applicability of RSM (CCD) in optimization processes. Our results suggested that statistical optimum strategy is an effective tool to predict the biodegrading activity of SBU1. However, the examined bacterial strain showed low biodegrading efficiency in general and even after optimization. This could be due to the nature of the strain or the limited knowledge about the environmental factors affecting the biological activity of the strain.

\section{Acknowledgements}

The work described was substantially supported by a grant from Pars Oil and Gas Company (POGC) [Grant number: 91-212].

\section{Financial Disclosure}

Authors don't have any financial disclosure.

\section{Funding/ Support}

Funding for this work was provided by the Shahid Beheshti University, G.C. and POGC.

\section{Authors' Contribution}

Mohsen Shahriari Moghadam contributed the statistical analysis and interpretation of data, wrote the manuscript, and was the guarantor. Gholamhossein Ebrahimipour, Behrooz Abtahi and Alireza Ghassempour provided the original idea and developed the protocol and critical revisions of the manuscript.

\section{References}

1. Tam NFY, Ke L, Wang XH, Wong YS. Contamination of polycyclic aromatic hydrocarbons in surface sediments of mangrove swamps. Environ Pollut . 2001;114(2):255-263.

2. Yu KS, Wong AH, Yau KW, Wong YS, Tam NF. Natural attenuation, biostimulation and bioaugmentation on biodegradation of polycyclic aromatic hydrocarbons (PAHs) in mangrove sediments. Mar Pollut Bull. 2005;51(8-12):1071-7.

3. Chen JL, Au KC, Wong YS, Tam NF. Using orthogonal design to determine optimal conditions for biodegradation of phenanthrene in mangrove sediment slurry. J Hazard Mater. 2010;176(13):666-71.

4. Wu YL, Wang XH, Li YY, Hong HS. Occurrence of polycyclic aromatic hydrocarbons (PAHs) in seawater from the Western Taiwan Strait, China. Mar Pollut Bull. 2011;63(5-12):459-63.

5. Coral Gökhan, Karagoz S. Isolation and characterization of phenanthrene-degrading bacteria from a petroleum refinery soil. Annal Microbiol. 2005;55(4):255.

6. Juhasz Albert L, Naidu Ravendra. Bioremediation of high molecular weight polycyclic aromatic hydrocarbons: a review of the microbial degradation of benzo[a]pyrene. Int Biodeterioration \& Biodegradation. 2000;45(1-2):57-88.

7. Chen J, Wong MH, Wong YS, Tam NF. Multi-factors on biodegradation kinetics of polycyclic aromatic hydrocarbons (PAHs) by Sphingomonas sp. a bacterial strain isolated from mangrove sediment. Mar Pollut Bull. 2008;57(6-12):695-702.

8. Li CH, Wong YS, Tam NF. Anaerobic biodegradation of polycyclic aromatic hydrocarbons with amendment of iron(III) in mangrove sediment slurry. Bioresour Technol. 2010;101(21):8083-92.

9. Tam NFY, Guo CL, Yau WY, Wong YS. Preliminary study on biodegradation of phenanthrene by bacteria isolated from mangrove sediments in Hong Kong. Marine Pollution Bulletin. 2002;45(1):316-324.

10. Zhou HW, Luan TG, Zou F, Tam NF. Different bacterial groups for biodegradation of three- and four-ring PAHs isolated from a 
Hong Kong mangrove sediment.J Hazard Mater. 2008;152(3):117985.

11. Rodriguez-Blanco A, Antoine V, Pelletier E, Delille D, Ghiglione JF. Effects of temperature and fertilization on total vs. active bacterial communities exposed to crude and diesel oil pollution in NW Mediterranean Sea. Environ Pollut. 2010;158(3):663-73.

12. Simarro Raquel, González Natalia, Bautista LFernando, Molina MCarmen, Schiavi Emanuele. Evaluation of the Influence of Multiple Environmental Factors on the Biodegradation of Dibenzofuran, Phenanthrene, and Pyrene by a Bacterial Consortium Using an Orthogonal Experimental Design. Water, Air, \& Soil Pollution. 2012;223(6):3437-3444.

13. Xia WX, Li JC, Zheng X L, Bi X J, Shao J L. Enhanced Biodegradation of Diesel Oil in Seawater Supplemented with Nutrients. Engineering in Life Sciences. 2006;6(1):80-85.

14. Nasrollahzadeh HS, Najafpour GD, Aghamohammadi N. Biodegradation of phenanthrene by mixed culture consortia in batch bioreactor using central composite face-entered design. Int J Environment Res. 2007;1(2):80-87.

15. Whitman William B, Goodfellow Michael, Kämpfer Peter, Busse Hans-Jürgen, Trujillo Martha E, Ludwig Wolfgang, et al. Bergey's manual® of systematic bacteriology:: Springer; 2012.

16. Wu Yi-Rui, Luo Zhu-Hua, Vrijmoed LLP. Biodegradation of anthracene and benz[a]anthracene by two Fusarium solani strains isolated from mangrove sediments. Bioresour Technol. 2010;101(24):9666-9672.

17. Li Yin, Lu Jian, Gu Guoxian, MAO Zhonggui. Characterization of the enzymatic degradation of arabinoxylans in grist containing wheat malt using response surface methodology.J American Society Brewing Chemists. 2005;63(4):171-176.

18. Shiaris MP. Seasonal Biotransformation of Naphthalene, Phenanthrene, and Benzo[a]pyrene in Surficial Estuarine Sediments.
Appl Environ Microbiol.1989;55(6):1391-9.

19. Lai Q, Zhong H, Wang J, Yuan J, Sun F, Wang L, et al. Roseovarius indicus sp. nov., isolated from deep-sea water of the Indian Ocean. Int J Syst Evol Microbiol. 2010;61(9):2040-2044.

20. Vila J, Maria Nieto J, Mertens J, Springael D, Grifoll M. Microbial community structure of a heavy fuel oil-degrading marine consortium: linking microbial dynamics with polycyclic aromatic hydrocarbon utilization. FEMS Microbiol Ecol. 2010;73(2):349-62.

21. Casellas Mercè, Grifoll Magdalena, Sabaté Jordi, Solanas Anna Maria. Isolation and characterization of a 9-fluorenone-degrading bacterial strain and its role in synergistic degradation of fluorene by a consortium. Canadian J Microbiol. 1998;44(8):734-742.

22. Chen Shaohua, Hu Qiongbo, Hu Meiying, Luo Jianjun, Weng Qunfang, Lai Kaiping. Isolation and characterization of a fungus able to degrade pyrethroids and 3-phenoxybenzaldehyde. Bioresource Technol. 2011;102(17):8110-8116.

23. Chen Shaohua, Luo Jianjun, Hu Meiying, Lai Kaiping, Geng Peng, Huang Huasheng. Enhancement of cypermethrin degradation by a coculture of Bacillus cereus ZH-3 and Streptomyces aureus HP-S-01. Bioresource Technol. 2012;110:97-104.

24. Lin Chen, Gan Li, Chen Zu-Liang. Biodegradation of naphthalene by strain Bacillus fusiformis (BFN). J Hazard Materials. 2010;182(13):771-777.

25. Leahy JG, Colwell RR. Microbial degradation of hydrocarbons in the environment. Microbiol Rev.1990;54(3):305-15.

26. Mohn William W, Stewart Gordon R. Limiting factors for hydrocarbon biodegradation at low temperature in Arctic soils. Soil Biol Biochem. 2000;32(8-9):1161-1172.

27. Margesin R, Schinner F. Biodegradation and bioremediation of hydrocarbons in extreme environments. Appl Microbiol Biotechnol.2001;56(5-6):650-663. 